\title{
Between Public and Private, Britain and Canada: Newfoundland Radio 1934-1949
}

Dr Ieuan Franklin

Correspondence: Faculty of Media and Communication, Bournemouth University, BH12 5BB.

Email: ifranklin@bournemouth.ac.uk

This article examines Newfoundland radio during the period when Newfoundland was governed by a British-appointed Commission of Government (1934-1949), devoting particular attention to the political sensitivities and implications involved when one nation essentially assumed control of radio broadcasting in one of its dominions. The BBC had played the role of midwife in bringing the Broadcasting Corporation of Newfoundland into being during the 1930s, and provided regular advice to the Commission of Government, at a time when the countries of the empire were encouraged to follow the Corporation's public service organization as a model. The relationship between the $B B C$ and the $B C N$ did come to sour, however, due to a feeling in St. John's that the larger Corporation was neglecting its tiny counterpart. As will be demonstrated using archival sources, there was some justification for this. Due to the particular constitutional status of Newfoundland, as in effect a Dependency of the United Kingdom, the BBC did not treat it on a par with the self-governing Dominions, which meant that possibilities for exchange were limited or non-existent. As well as examining these political issues, the article will develop a portrait of the unique aspects of Newfoundland's early radio culture. Newfoundland is a particularly appropriate case study for radio beyond boundaries as, due to its geographical location, listeners have traditionally been exposed to US and Canadian radio stations as well as domestic broadcasters and short- 
wave frequencies. Furthermore, conventional boundaries between public and private models of broadcasting do not apply in Newfoundland, where commercial radio programming has often performed a valuable public service function.

In the scholarly literature on the British Broadcasting Corporation (henceforth BBC) and the British Empire, there is a clear distinction made between the development of policy regarding (self-governing) dominions and dependent colonies, regarding the Corporation's notably greater efforts to make connections with the former in comparison to the latter. ${ }^{1}$ This article will explore an example which doesn't fit this overly neat distinction, and which casts light on other aspects of the 'hidden' bias of the Corporation's policy in this area. Newfoundland is a country which took the highly unusual step of giving up its hard-won self-governing status, and it therefore has defied easy categorization. It is also a country where the BBC did play a significant role in shaping broadcasting culture and policy, despite - and, indeed, because of - Newfoundland's dependent status. Summarising the rise and fall of the 'British world', Simon Potter states that,

By the early twentieth century, the constitutional autonomy of the settler dominions had grown considerably to match their ability to shoulder the costs of self-rule, again in marked contrast to the tropical dependencies. In Canada, Australia, and South Africa, separate colonies came together into large regional groupings, based on various forms of federal organization... ${ }^{2}$

Newfoundland does not fit into even this broad narrative of empire, as it did not join in Confederation with Canada until 1949, and during the 1930s it was not able to shoulder the cost of self-rule. Before joining Canada there had already been 'a century of various projects 
of state formation and "nationalisms" of one kind or another that defined Newfoundland as a distinct political and cultural entity, ${ }^{3}$ including the achievement of formal status as a Dominion in $1927 .{ }^{4}$ Government attempts to develop economic alternatives to the fishery through modern transportation and communication industries, however, contributed to a debt burden that Newfoundland was unable to sustain when exports collapsed during the Great Depression. By 1932, one-quarter of Newfoundland's population was on the dole. ${ }^{5}$ By 1933 there was a public debt of over $\$ 100$ million - and at this time Newfoundland's national income was just $\$ 30$ million. ${ }^{6}$ When the Newfoundland government turned to the British government for help, a royal commission was appointed under Lord Amulree, which produced a report critical of what it regarded as Newfoundland's profligate public spending and political corruption, and recommending a 'rest from politics'.

These serious financial difficulties precipitated the extraordinary events of 19331934: following the recommendations of the Amulree Report the constitution was suspended, and Newfoundland reverted to something approximating the status of a crown colony. On $16^{\text {th }}$ February 1934, responsible government came to an end when a paternalist Whitehallappointed 'Commission of Government' was sworn in - consisting of six commissioners appointed by and responsible to the Dominions Office in London (three from Britain and three from Newfoundland). ${ }^{7}$

The fact that a large proportion of the Newfoundland population was apparently willing to accept this abnegation of democracy in favour of 'technocratic' rule from Whitehall undoubtedly had something to do with Newfoundland's strong sense of its ties and deep connections with Britain. Even after it became self-governing, many Newfoundlanders continued to regard their country as Britain's oldest colony. On $8^{\text {th }}$ June 1966 an episode of the Canadian Broadcasting Corporation (CBC) documentary series Between Ourselves entitled The Gulf was broadcast, which looked at Confederation and Newfoundland's 
relationship with Canada - whether there was a 'union in spirit as well as a union in law'. The presenter David Gunn, who also wrote and produced the programme, wondered if, living on an island, it was 'perhaps more difficult for Newfoundlanders to feel they were part of a larger identity'. He continued,

Geographically we remained separate. But our economic, political and cultural context had suddenly changed. Our horizons had broadened, and it was vital for our survival that we become involved in Canadian affairs [...] The British heritage has always played a strong role in Newfoundland - the Mother Country enjoys a special place in the hearts and minds of Newfoundlanders. Our ties are strong, too, with the United States. Now that our interests lie with the West, are we in danger of drifting away from our old traditions? $?^{8}$

On 29 October 1948 Michael Barkway, the Canadian Representative of the BBC Overseas Services, sent a memo to his boss J. B. Clark, then Deputy Director of Overseas Services, about changes anticipated in the run-up to Confederation. This drew on a recent conversation he had had with William Galgay, the manager of the station VONF, operated by the Broadcasting Corporation of Newfoundland (BCN):

The $\mathrm{BCN}$ has to provide numerous basic services, such as bulletins to fishermen and outports, and it is about the only available means of conveying information about Government decisions and regulation to most of the inhabitants. Galgay thinks that an enormous amount of explanation of Canadian laws and methods of government will have to be given and that it will all have to be interpreted by the BCN people at St. John's. Direct news and comment from Ottawa would, he thinks, be quite unintelligible. There is clearly a big problem here. ${ }^{9}$ 
One of the remarkable things about this situation is that less than ten years previously the $\mathrm{BCN}$ had been founded for this primary reason - to convey information about policy and regulation - by a government which answered to the British Parliament rather than the people of Newfoundland. Now the station owned by the BCN readied itself for incorporation within the CBC, just as Newfoundland readied itself to be incorporated into Canada. Forwarding Barkway's ominous missive to BBC mandarins, including the then Director-General William Haley, Clark was harsh in his summation of the BCN's record:

The job which broadcasting will have to do in Newfoundland in securing understanding of the future constitutional position will no doubt be one of great interest and importance. Unfortunately, the Broadcasting Corporation of Newfoundland has in the past shown no material enterprise or ability, so it seems doubtful whether the job will be well tackled. ${ }^{10}$

Now this is a rather damning indictment, especially as the BBC had played the role of midwife in bringing the BCN into being during the 1930s, a time when the Corporation had encouraged the countries of the empire to follow its public service organization as a model. In the context of the need to inform the population about constitutional matters Clark's judgement was also highly questionable, as the BCN had recently - between October 1946 and January 1948 - embarked on and implemented an 'ambitious project that fulfilled the highest potential of public broadcasting and exemplified the impact broadcasting could have upon political life'. ${ }^{11}$ This was the broadcasting of the constitutional debates of the Newfoundland National Convention. ${ }^{12}$ 
Given, then, the closeness of the relationship between Great Britain and Newfoundland during the Commission of Government period, and the role played by the $\mathrm{BBC}$ in creating the $\mathrm{BCN}$, why did the Corporation come to hold Newfoundland radio in such low esteem? This is the central question that this article will seek to answer.

\section{Broadcasting Policy in Newfoundland}

Given the 'emergency' nature of the government and the dire state of the public finances, it might at first seem surprising that the Commission of Government devoted attention and resources to broadening and improving radio coverage and programming in Newfoundland, with the support of both British civil servants and the BBC. But radio was thought to have significant potential to provide support in a time of depression and reconstruction, especially in a country where communications were poor. Many coastal settlements (known as outports) lacked telephones, telegraph communication and regular newspapers. ${ }^{13}$ They were often accessible solely by boat or 'plane and were further isolated by the presence of offshore ice during the coldest months.

The unusual political conditions in Newfoundland meant that, other than the small commercial radio 'lobby', there was little or no effective resistance to state-owned public broadcasting. The situation can be contrasted to that which pertained in Canada at the time, where resistance to the establishment of a public broadcaster was expressed powerfully from those who cast doubts about the allocation of resources in a time of economic depression, and from those who had an aversion to examples of 'activist government'. ${ }^{14}$ Nevertheless, it is also important to bear in mind the unstated assumption in many histories of radio broadcasting that privately-owned stations serve merely their owners' or shareholders'

interests and that 'state-ownership is synonymous with public broadcasting', ${ }^{15}$ which has 
often perpetuated a crude and unhelpful public/private dichotomy. Michele Hilmes has argued, for example, that during the 1920s and 1930s the dichotomy between 'British quality' and 'American chaos' served to mask the fact that the two systems sought to dominate the media ecologies in their respective countries and to contain or limit the scope of a 'decentralised, open access, minority and community-based model of truly popular broadcasting' (which did not conform to either of the public/private models). ${ }^{16}$ In Canada there was, for example, the Canadian National Railways (CNR) Radio network, which launched in 1923 to provide 'on-board' entertainment and information for its transcontinental train passengers, including educational programmes for children. ${ }^{17}$ Although it was developed, owned and operated by the state-owned CNR, it was nonetheless a commercial network as its first priority was to attract travellers to CNR trains. And despite this orientation, it was absorbed into the Canadian Radio Broadcasting Commission (the forerunner to the CBC) in 1933.

As Webb has pointed out, the church-owned 8WMC (later renamed VOWR), founded in 1924, was in many respects Newfoundland's first community radio station, bringing church services to 'shut-ins' (citizens with limited mobility and thus confined indoors). In Newfoundland it was also common for programmes that were sponsored or featured advertising to perform an essential public service role, as we will later see with the example of The Gerald S. Doyle Bulletin. Churches and private businesses were thus the first public broadcasters in Newfoundland for a relatively long period before the state was even involved in the regulation of broadcasting. ${ }^{18}$

Newfoundland provides a fascinating case study of 'radio beyond boundaries' due to its particular geographical location, which meant that listeners could easily pick up frequencies from American and Canadian stations in addition to the local Newfoundland stations and short-wave frequencies from Europe (notably including the BBC's 
Empire/Overseas Service/North American Service). ${ }^{19}$ As Vipond has noted, it has been estimated that during the late 1920 s $80 \%$ of Canadians were within range of the powerful broadcasting stations of the United States, ${ }^{20}$ and it was largely the threat of Canada being 'swallowed up' in the powerful American radio system that impelled the federal government to consider the establishment of a nationwide public broadcaster in the first instance. Yet in Newfoundland the establishment of a public broadcaster was predicated on the potential of radio as a tool for social change and economic recovery and development, rather than as a means of countering commercialism or forging national identity. As Jeff Webb has argued,

The principal motivation for creating a Newfoundland equivalent of the BBC and $\mathrm{CBC}$ was its potential as a tool to effect social change. As such, it fit into the Commission's broader agenda of preparing the country for the return to responsible government. $^{21}$

The Broadcasting Act ultimately drafted by the Commission of Government in 1938 was based heavily on the CBC (Canadian Broadcasting Corporation) Act of 1936. In Canada the Aird Commission had originally advocated the public service model of broadcasting beginning to flourish in Europe, recommending what was essentially a cross between the $\mathrm{BBC}$ and the German 'federated' public radio system. ${ }^{22}$ As a result of the previously cited political pressures ultimately a compromise was reached with the private radio sector, whereby private stations would continue to coexist alongside what became the CBC. In Newfoundland it was decided that a similarly 'mixed' broadcasting system was best suited to local conditions, although the Commission of Government decided to not grant any additional commercial licences, or to allow the existing commercial stations to expand their coverage. The reorganisation of broadcasting in Newfoundland was described in the BBC 
publication World-Radio as 'a compromise between that of the British Broadcasting Corporation and the Canadian Broadcasting Corporation'. ${ }^{23}$

Although the $\mathrm{BBC}$ and the Dominions Office wholeheartedly backed the creation of a semi-autonomous corporation along the lines of the Broadcasting Corporations in the UK and Canada, there was an interesting debate about issues of censorship, as chronicled by Webb. ${ }^{24}$ It is worth noting, in addition, that the Commission of Government had sought advice from the $\mathrm{CBC}$ on the topic of free speech well in advance of the concerns being raised at the Dominions Office. In September 1937 G. D. Frazer wrote to Gladstone Murray, who had formerly been the BBC's Director of Publicity and who had become the CBC's first General Manager, to 'ask your advice with reference to the question of free speech over Government Radio stations and the use of those stations for the broadcasting of political and other matters of contentious issue'. ${ }^{25}$

In their correspondence with St. John's the BBC for their part were generally more concerned that the financial scheme for the $\mathrm{BCN}$ was overly optimistic. It was only in private that the Corporation expressed reservations about issues of administrative control. On reviewing the Newfoundland broadcasting act, the BBC's in-house lawyer R. Jardine Brown commented in an internal memo to J.C.S. Macgregor, the new Empire Service Director, that,

As compared with the $\mathrm{BBC}$ there is nothing like the same degree of independence and the NBC [sic] will theoretically at any rate be, even in matters of detail, under the thumb of the Government...the new act...creates not an independent Corporation, but an organisation which will become part of the Government Administrative Service. ${ }^{26}$ 
If this was true then in a sense the corporation mirrored the constitutional position of Newfoundland itself, as the state apparatus was for all intents and purposes a subdivision of the British civil service.

\section{Constitutional Issues}

It might have been surmised that the $\mathrm{BBC}$ would assume a harmonious relationship with the $\mathrm{BCN}$, especially given the prominent part played by the $\mathrm{BBC}$ in bringing it into existence via a seminal report written by the BBC's Empire Service Director Sir Cecil Graves ${ }^{27}$ and subsequent visits, reports and recommendations by Corporation staff. Any such notion, however, is complicated by an internal memo sent from the Acting Controller of the Overseas Service, R. A. Rendall, to the then Director General, William Haley, dated $22^{\text {nd }}$ May 1945, which looks back at the history of the relationship. Referring to a letter from George Williams, Chairman of the BCN, which complained about the BCN's exclusion from the inaugural Commonwealth Radio Conference of that year, it is worth quoting at length due to its informative and revelatory nature.

This reproach is not altogether unexpected. For some years our relations with the Newfoundland Broadcasting Corporation [sic] have been uneasy. This is entirely due to the complex constitutional position. Since Newfoundland lost her Dominion status and was governed by a Commission responsible to His Majesty's Government in the United Kingdom, we have not treated her on a level with the self-governing Dominions. This is in accordance with advice received from the Dominions Office that Newfoundland should be regarded constitutionally as being in a position approximately the same as Southern Rhodesia (to which the India Office would add 
Burma) rather than as Canada, Australia, New Zealand and South Africa. This has led to difficulties not only in respect of invitations to the Commonwealth Broadcasting Conference but also in regard to contributions to Empire round-up programmes on Christmas Day, Empire Day, VE-Day, etc.; the root of the trouble being that Newfoundland, not unnaturally, is anxious to maintain the position which she gained when a self-governing Dominion. Although the BBC, through Sir Cecil Graves' report, played a prominent part in the decision to set up a broadcasting corporation in Newfoundland, and our relations ever since have been reasonably close, it simply has not been possible - owing to the size of the country and paucity of talent available to establish relations as close as those existing with the self-governing Dominions and India. It was on these grounds as much as on constitutional grounds that $\mathrm{Mr} \mathrm{J}$. B. Clark and I decided, after consideration, against suggesting the inclusion of Newfoundland in the conference... ${ }^{28}$

This tends to reinforce Hale's assertion that during Confederation Newfoundland 'experienced a form of political punishment and national humiliation for its debt problems', ${ }^{29}$ as it lost status and privileges accorded to self-governing dominions. It is also evidence of how scrupulously the BBC's Empire Service followed the advice of the Dominions Office in deciding how much support should be given to the various components (or past components) of the British Empire.

Naturally the relationship between the BBC and the Dominions Office was especially close during the Second World War, and Simon Potter has asserted that "from the late 1930s onwards, the BBC was used by the state as a subcontractor for the purposes of 'cultural diplomacy"". ${ }^{30}$ The Dominions Office played a key role, for example, in helping the BBC's External Services formulate their policy regarding message programmes directed at Canadian 
and Newfoundland troops stationed in the UK. As Sian Nicholas has documented, the arrival of the Dominions expeditionary forces in Britain was reflected in domestic broadcast schedules. By the end of 1942 the BBC Forces Programme was broadcasting over two hours a week of material for Canadian troops, in order to provide entertainment for Dominion troops stationed in Britain, and to encourage home identification with these troops as an integral part of the British Empire's war effort. ${ }^{31}$ Nevertheless, as we have seen, an unspoken colonial hierarchy was at work, which meant that 'despite regular representations calling for equal recognition of the 'oldest Dominion', the $\mathrm{BBC}$ refused to institute a Calling the Newfoundlanders message programme on the Forces Programme. ${ }^{32}$

The BBC did, however, create two programmes specifically for Newfoundland (as it had done for Canada, the United States, and the West Indies) on its short-wave Overseas Service and North America Service - one variously titled Calling Newfoundland or Hello Newfoundland, and the other known as the Newfoundland Newsletter. The long-running Calling Newfoundland was highly popular, and is still fondly remembered, especially its Newfoundland-born host Margot Davies (daughter of D. J. Davies, Newfoundland's trade commissioner in the UK), who began broadcasting on 23 April 1941 and continued as host until shortly before her death in 1972 . This bi-weekly programme was established by the $\mathrm{BBC}$ in 'recognition of the need for the men of the Newfoundland fighting forces to have some contact with their families and friends at home'. ${ }^{33}$ In relaying messages sent across the Atlantic from family and friends, the programme happened to serve a very similar function to pre-existing Newfoundland programmes such as The Gerald S. Doyle Bulletin (discussed below), giving individual people the opportunity to communicate messages that would otherwise be sent by telegraph, but this time across national borders. ${ }^{34}$ As with the Doyle Bulletin, the $\mathrm{CBC}$ recognized the special role that the programme played in Newfoundland, and ensured its continuation after Confederation. 
Notwithstanding Galgay's alleged admission to Michael Barkway that 'the truth is one or two of us thought we might get a trip out of it, and were disappointed', ${ }^{35}$ the fact that the $\mathrm{BCN}$ was excluded from the first Commonwealth Broadcasting Conference is not insignificant. ${ }^{36}$ The BBC Year Book of 1946 refers to the Conference as inaugurating a 'new chapter' or phase in the Corporation's 'intra-Commonwealth and Empire broadcasting', specifically the third phase of what was clearly promoted as an increasingly bilateral or multidirectional network. ${ }^{37}$ Accordingly the Corporation aimed to move beyond the idea of empire broadcasting 'as an activity largely to be carried out in and coordinated from Britain' ${ }^{38}$ The first phase had been the era of short-wave broadcasting to British 'exiles' scattered around the globe. The second had revolved around 'rebroadcasting' - 'the relay by the broadcasting organizations of the Dominions and elsewhere of programmes which they picked up direct from London and broadcast from their own programme service' ${ }^{39}$ As Potter has explained, the BBC hoped to cement 'imperial unity', through the dissemination of its programmes around the empire, by the rebroadcasting by partner organizations (such as the $\mathrm{BCN}$ ) of material supplied to them via the BBC's Transcription Service (on disc) and Empire Service (via short-wave transmissions). ${ }^{40}$ The theme of the third phase was exchange - of programmes, news, information, and staff - and this was also the theme of the Commonwealth Conference. It should be noted, however, that the ideological basis of the Conference precluded it from being truly inclusive or from achieving anything approaching the desired 'pooling of resources' of the Commonwealth. The BBC's Kenneth Adam later reflected that:

In 1945 [the Conference] was very much a “white man’s club," with India alone of the newer countries joining the old family of the United Kingdom - Australia, 
Canada, New Zealand, and South Africa. It was a family committed to the continued establishment of the "British way of life". 41

Given the importance of the constitutional issue, why did Rendall refer to Newfoundland's exclusion as being equally attributable to 'the size of the country and the paucity of talent available'? Potter has explained that the uneven distribution of people and radio audiences always made it 'unlikely that the exchange of cultural influences within the English-speaking world would take place on equal terms'. ${ }^{42}$ In the 1930 s Britons in the UK outnumbered their Canadian Anglophone counterparts approximately seven-to-one, Canada containing a potential audience equivalent in size to one of the larger UK broadcasting regions. Newfoundland, with its tiny population (in 1935 the population was 289,588 ) had a correspondingly small claim on the BBC's attention. Ultimately Newfoundland was also less important as a trading partner or military ally than other dominions, despite its strategically important location as a kind of gateway to North America. Furthermore, although Newfoundland had adopted the title 'dominion' it did not adopt legislation putting into operation the Statute of Westminster (1931), so did not in any case have the same level of independent legal personality as did Commonwealth countries like Canada and Australia. ${ }^{43}$

Regarding the question of talent, we can turn to the minutes of the Conference, in which the Director General William Haley warned that, whilst the BBC planned to increase the amount of reciprocal material from the Commonwealth included in its schedules, available space was limited. While programme exchanges could promote 'understanding and goodwill among the peoples of the Commonwealth', they had to be justified in terms of 'their intrinsic appeal to the listening public of the receiving country' ${ }^{44} \mathrm{BBC}$ listener research had showed that 'home' interest in radio coverage of the empire was, sadly, very limited. ${ }^{45}$ Whilst the Conference was supposed to inaugurate a new phase of 'exchange' in broadcasting to 
(and now 'from' or 'with') the dominions, unspoken hierarchies were clearly in place regarding the constitutional status and programming standards that pertained within each country, bolstered by the apparent public apathy in the UK towards (broadcasting about or from) the empire and commonwealth. Speaking about what he perceived to be the bureaucratic, pedantic, and superior attitude of senior BBC executives, Andrew Cowan of the CBC Overseas Unit and the CBC London office), remarked,

The BBC suffers from what I call institutional arrogance. It is a form of imperialism. They unconsciously feel that they have the best broadcasting system in the world, staffed by the best possible people, producing the best possible programmes in the best possible way. While they look for an unrestricted export of their culture, they have a high tariff policy towards any incoming material. ${ }^{46}$

Memoranda within the BBC Written Archives make it clear that staff within the BBC North American Service were keen to discover how they might adapt and improve programmes like Calling Newfoundland, and to seek out programme suggestions from William Galgay. ${ }^{47}$ Staff involved in Empire Transcriptions were keen to counter American 'influence' and so generously provided transcriptions to the Broadcasting Corporation of Newfoundland at a greatly reduced price for many years ( $£ 3$ per hour, rather than $£ 10$ ). But the 'high tariff policy towards any incoming material' meant that requests for programmes could even be used for the purposes of leverage. In 1946, immediately following the BCN's 'reproach', Michael Barkway visited Newfoundland and wrote a report for the BBC. Mentioning that he had requested three programme items from the $\mathrm{BCN},{ }^{48}$ he commented that, 
Galgay, fearing work, found a large number of reasons why these things would be very difficult to do; but I was able to tell the Board that if we didn't get these the BBC could never again be accused of ignoring Newfoundland. ${ }^{49}$

In his history of the BCN Webb (drawing upon a letter sent from J. B. Clark to Michael Barkway on 18 January 1946) comments that 'the BBC maintained that it selected its [Christmas Day] programme for aesthetic quality, rather than territorial representation'. ${ }^{50}$ As this is problematised by Rendall's comments on the size and (constitutional) status of Newfoundland less than a year previously, it would seem that it was only at the very highest levels of the Corporation that the full rationale for the exclusion of Newfoundland was acknowledged.

As Webb has explained, the $\mathrm{BBC}$ and $\mathrm{CBC}$ provided advice and programming to the smaller corporation, but rarely rebroadcast programming that originated in St. John's. Newfoundland were stuck within the rebroadcasting chapter of empire broadcasting and would only discover the possibilities of exchange when they were incorporated into the federal structure of the $\mathrm{CBC}$. To this end it is worth noting that the $\mathrm{BCN}$ had received a far more positive message regarding exchange from the $\mathrm{CBC}$ even before the $\mathrm{BCN}$ had been officially launched. This was from Gladstone Murray, who wrote to G. D. Frazer in 1938 to explain that the $\mathrm{CBC}$ 's cooperation with the $\mathrm{BCN}$ 'is not unselfish because I know that the considerable unexplored artistic resources of what I still prefer to regard as the oldest dominion of the commonwealth will enrich our broadcasting services by exchange'. ${ }^{51}$

\section{Programming and Social History}


We can surmise that Frazer received Murray's sentiment with some scepticism, as the previous year he had written a report on broadcasting in Newfoundland which was highly critical of existing (commercial) radio content and which remarked that, in addition to the role of the proposed new service in 'the enlightenment and education of the more backward sections of the population...', ‘...[even] entertainment broadcasts from British sources, and in particular the Empire service, may have over a period a considerable beneficial influence'. ${ }^{52}$ Sentiments were often expressed privately by BBC staff that Newfoundland lacked talent, and that the Commission of Government were overly optimistic about the number of broadcasting hours that could be filled by it. Cedric Cliffe, for example, believed that the 'staple fare' would have to be the relaying of suitable $(\mathrm{BBC})$ programmes from Daventry, which he believed would 'strengthen the ties with this country while at the same time providing entertainment' 53

This can be largely attributed to a cultural tendency or problem within the BBC's Empire Service, which often seemed to regard the dominions merely as audiences for the Corporation's programmes, rather than broadcasting ecologies with their own pre-existing values and traditions. In the dominions during the 1930s some alleged that the BBC was perpetuating a kind of cultural imperialism by 'encouraging an unreciprocated flow of material out from London and refusing to broadcast programmes from the dominions to listeners in Britain' ${ }^{54}$ Yet, although they did play a significant role, BBC programmes did not become the envisioned 'staple fare' of Newfoundland radio in the years to come.

The relaying of $\mathrm{BBC}$ productions to broadcasters in the dominions took on a new urgency in the wartime and post-war period. As Len Kuffert has noted, 'While visions of a reinvigorated Commonwealth connection may have buoyed spirits, the $\mathrm{BBC}$ also tried to defend itself and other commonwealth broadcasters against a tide of commercialism in the late 1940s and early 1950s' 55 To quote the BBC's Empire Services Director J.C.S. 
Macgregor, the $\mathrm{BBC}$ was cognisant of the importance of 'providing British material in a territory where American influence is very strong indeed. We have to remember that American transcriptions are available in enormous quantity, and at very low cost' ${ }^{56}$ Although it appears that the $\mathrm{BBC}$ were right to suspect that VONF was tending to under-utilise the transcription service programmes in favour of US programming, it must be remembered, to quote Kuffert, that 'the primary purpose of each organisation was serving its own listening public, and programmes produced in one place would not always be considered a good fit for listeners in the other... ${ }^{57}$ Galgay was, naturally, keen to reaffirm to the Corporation the importance of the BBC programmes in reinforcing cultural links and in ensuring that listeners did not require an overly American outlook, especially given the appetite for American popular culture amongst Newfoundlanders. Webb has noted that the ability of Newfoundland listeners who owned commercially built radio receivers to pick up eastern Canadian and American stations had shaped their expectations of radio content. ${ }^{58}$ This served to precipitate a lively debate among broadcasters and listeners between those who wanted American popular culture, and those who wanted greater 'British' character to their broadcasting, particularly during the immediate post-war period (1945 to 1949$).{ }^{59}$ This was probably more or less in line with other 'settler dominions', where 'an appreciation of sophisticated British cultural exports offered would-be cultural elites a means to assert their own authority', and thereby also devalue 'folk' or 'popular' forms. ${ }^{60}$

It should be noted that the Commission of Government did set out to encourage local Newfoundland production and talent, but that it certainly did not reflect the broad spectrum of Newfoundland culture. The 'local talent' used on the air conformed to an international elite cultural standard (which predominated within the BBC). But there was undoubtedly also a rather dismissive attitude towards broadcasting in the dominions. To return to Barkway's 1946 report, which is sharply critical of the Corporation and of VONF's output: 
$\mathrm{BCN}[\mathrm{VONF}]$ is by far the most important medium of communication across the island... With this great opportunity, the BCN has sold nearly all of its good time to commercial sponsors most of whom run soap operas, or even announcements of bargains. A 15-minute programme at 7.30 every night consists entirely of 'want ads' or of objects for sale.

As 'a BBC man' it is not surprising that Barkway objects to what he clearly regards as the 'lowest common denominator' standards of commercial broadcasting, and his views were shared by Robert S. Furlong. A member of BCN's Governing Board, Furlong had prepared a confidential report on programming to the Board the previous year, which was highly critical of the pervasive nature of advertising and the 'slick' and 'insincere' announcers within the commercials, and called for regular use of the BBC's London Transcription Service. ${ }^{61}$ However, as Webb notes, the very much larger and well-financed BBC was not really a fair basis of comparison in assessments of Newfoundland radio by BBC executives. ${ }^{62}$

Barkway fails to recognise that, especially to an impoverished outport community who could not receive copies of newspapers published in St. John's, some of the programmes that were sponsored, or which featured advertising, performed a function which in other countries would be served by newspapers or telephones. Programmes like Bargain Hour (to which Barkway refers), The Big Six and The Doyle Bulletin (discussed below) were like radio versions of the classified ads section of a newspaper. The Barrelman began as a newspaper column by Joseph Smallwood which was then transferred to radio. ${ }^{63}$ Like the later Open Line phone-in programmes, these programmes were interactive, combined entertainment and information, and filled a kind of social niche. ${ }^{64}$ 
An area where the Commission of Government and the BBC did have a clear influence was in the provision of radio news from Britain during the Second World War, which reinforced a sense of connection to the 'Old Country'. In addition to the daily VONF rebroadcast of the $\mathrm{BBC}$ news, the $\mathrm{BCN}$ also contracted the British-based news service Reuters as a source of international news. As the Reuters service was designed to inform North Americans of events in Europe, it created a peculiar situation where Newfoundlanders were relatively well-informed of events in Britain and Europe but had poor coverage of American and Canadian news, even though Newfoundland was part of North America. ${ }^{65}$ As Webb has noted,
Although Newfoundlanders were overwhelmingly native born, several factors reinforced people's sense of themselves as part of the empire. The Newfoundland government consisted in part of British civil servants, a large number of Newfoundlanders served in the British Armed Services, and many people thought of Newfoundland as 'Britain's oldest colony'. Newfoundlanders identified strongly with the UK, and hearing the British war news every day reinforced that feeling. ${ }^{66}$

This sense of identification is exemplified in the following anecdote, from an interview with the late Newfoundland CBC producer Kevin O'Connell. Whilst apocryphal, it also points to what we might term the 'concentrated' and collective nature of radio listening for many Newfoundlanders and Labradorians ${ }^{67}$ due to the lack of electricity in the outports:

Well [the Gerald S. Doyle Bulletin] was an institution, it knitted people together. Everybody sat and listened...Radio was very important in this respect...during the war, a salesman was travelling on the coast of Labrador, and they had battery radios 
up there because they had no electricity...you conserved your battery and just listened to what you wanted to listen to. Radio wasn't left on like it is today. So he went into this house where he stayed for a night and a certain time came when it was time for the BBC North American Service, the short-wave service of the BBC during the war, a critical time early in the war. And so suddenly the family...turned on the radio and they tuned into the BBC and they heard Big Ben striking, and they heard the announcer say 'This is London Calling, the Overseas Service of the BBC'. And they turned off the radio. And he said 'What's happening? Aren't you going to listen to the news?' 'No the battery is very low, we have to conserve it. Once we hear that [the Big Ben chimes], we know everything's OK'. So radio was extremely important to the people. $^{68}$

Contrary to the prevailing trend in North America, Newfoundland programmes that were sponsored or featured advertising could also perform an essential public service role. A preeminent example in Newfoundland radio history is the aforementioned Gerald S. Doyle Bulletin (aka the Gerald S. Doyle News), which began on VONF in 1932 and which has the status of the longest-running continually sponsored broadcast in Canadian radio history (it ran until 1966 with the same sponsor). The programme remained on VONF through ownership by the local Avalon Telephone Company, the BCN, and (after confederation with Canada in 1949) the CBC. It was thus symbolic of the maintenance of continuity in the character of Newfoundland radio, despite the tumultuous political and social changes the country underwent during these decades.

The Bulletin (as it was often simply known) provided essential information such as weather reports, obituaries, and notices of shipping, designed as it was to reach out to the people who lacked access to telephones and telegraphs, and who lived beyond the range of 
the daily newspapers printed in St. John's. In a very real sense the Bulletin was the audio equivalent of a newspaper. Individuals 'in town' (e.g. St. John's in the East or Corner Brook in the West) seeking to contact relatives, spouses, friends or workmates in the outports could deliver messages by telegram which would be paid for by Doyle himself (the programme's sponsor), and which would then be compiled into scripts read on the air by an announcer. Many of these messages could alert people to births, deaths or illnesses in their families. For example, a wife in hospital could let her husband know about her current status - the announcer would name the sender and recipient and relay the message. A 1947 magazine article on the Bulletin noted that it was no longer regarded as a 'straight commercial programme', as it placed emphasis on 'service to people rather than the selling of products'. ${ }^{69}$

Similar message programmes did exist elsewhere - for example, there was the Canadian Northern News, which was broadcast in 1948 by CKBI in Prince Albert, the city situated on the banks of the North Saskatchewan River which is now known as the 'Gateway to the North' ${ }^{70}$ It was hosted by Jean Doidge, a former schoolteacher and journalist who was employed within Saskatchewan's National Resources Department. Northern News was a fifteen-minute programme with 250,000 listeners, which ran for 12 years, knitting together the isolated communities and strung-out settlements of the North and providing an essential information for aboriginal people, trappers, fishers, prospectors, bush pilots, doctors and miners in the vast forests of Northern Saskatchewan. Audience participation was incorporated into Northern News on every Thursday, when a section of the programme was given over to the messages of listeners, sent by post or by telegraph. Like the Bulletin the personal messages on Northern News ranged in urgency and importance, from "do not send any fish, the weather is too mild, it would spoil" to "Your Dad passed away this morning, funeral services Monday..."71 
Whilst it is important to note that similar programmes to the Bulletin existed, it is also worth noting some immediate distinctions that can be made. For example, the Gerald $S$. Doyle Bulletin began much earlier and ran for a much longer period. It also broadcast a compendium of listener's messages on each broadcast, rather than once every week. Further, broader distinctions can also be made about the especial function of the Newfoundland Bulletin in a historical context and in the social context of outport culture. Philip Hiscock, for example, has discussed the Bulletin in the context of the community uses and criticisms of an earlier news medium, the Public Despatch, which was a 'daily electronic newspaper...compiled in St. John's from wire reports, local newspapers, and government notices, and...distributed through the Government's Post Office and telegraph system to most communities in the country'. ${ }^{72}$ Postmasters transcribed the Despatch as it came in each day off the wire, and posted it on bulletin boards in post offices for all to read. Stories have often been told in Newfoundland of communities where someone with an especially good reading voice (and the ability to read) was appointed reader each day as the news was posted. ${ }^{73}$ These quasi-broadcast performances quickly became a daily ritual, with the post office becoming a place for men to gather and talk, and so the 'informative function was supplemented by a purely social one' ${ }^{74}$ Hiscock relates this to wider outport culture:

News has served as a focus for social gathering in Newfoundland for some time. When news arrived by wire at the central place in the community, the post office, a crowd would gather in order to read it. In the outport, a gathering occurred wherever news came into the community, regardless of the medium: itinerant pedlars, coastal boats, post offices or radios. ${ }^{75}$ 
Radio in Newfoundland therefore did not so much supplant or even supplement but rather sustained a pre-existing pattern of communication whereby the boundaries which normally separate information and entertainment, and public and private, were often ignored or dissolved altogether. ${ }^{76}$ Yet despite its community uses, it should not be forgotten that the main purpose of the Public Despatch was to serve the government of the day. During the 1930s - for example in 1932, when riots in several Newfoundland communities were not even mentioned in the Despatch - listeners sometimes complained that it was a propaganda tool for the government, particularly compared with other news services. When the Commission of Government took control of radio broadcasting in Newfoundland they were keen to use radio as a means to promote their political (reconstruction) agenda but had to try to avoid VONF being seen merely as a mouthpiece for government propaganda in the same manner.

In the political context of Newfoundland's dire lack of autarky, the personal nature and function of the messages carried on The Gerald S. Doyle Bulletin was vital, despite their ostensibly mundane and quotidian character. These programmes were reliant on input and interaction from listeners and therefore provided something of a bulwark against the topdown, paternalist government. To return to Hiscock,

[T] he message programmes underlined Newfoundlanders' sense of nation at a time when their state had been taken away by the Commission of Government. The messages were listened to by a large and faithful audience, and became part of Newfoundland folklore, forming the core of many jokes and anecdotes which have been told and retold. Unlike the Despatch whose communicative axis was vertical from the Government down to the people - the message programmes provided a horizontal means of mass communication, communication among the listeners. ${ }^{77}$ 
It is also worth noting that, since at least part of the Bulletin each day was devoted to notices from Governmental agencies addressed to occupational communities or the entire population, anyone could listen to the programme and hear something directed to themselves. ${ }^{78}$

\section{Conclusion}

Webb's detailed history of the BCN provides ample evidence to refute Michael Barkway's judgement (in 1946) that 'there is no attempt at all on the part of the BCN to originate balanced discussion or talks on matters of public interest' ${ }^{79}$ It is also worth noting that, in a country which had for some time had no elections or political fora for debate, people were keen to seek interaction and dialogue through the medium of radio, or to write letters to

newspapers or to the $\mathrm{BCN}$ to express their views about radio programming. ${ }^{80}$ Nationalist aspirations were to some extent suppressed, but they nevertheless found expression in cultural forms which featured vernacular and subaltern input, such as the Barrelman programme. $^{81}$

It can be argued that the BBC executives and British civil servants who sought to intervene in Newfoundland radio lacked a sympathetic understanding of its unique character, and that it had developed very differently from radio in the United Kingdom (and, to a lesser extent, Canada). Jesus Martín-Barbero has conceptualised the medium of radio in Latin America as a bridge between the 'modernizing, informative-instrumental rationality' (associated with both literacy and development) and the 'expressive-symbolic mentality of the popular world' (associated with oral culture and popular culture) ${ }^{82}$ It might be said that the colonial and bureaucratic mindset - the dominance of 'informative-instrumental rationality' - within the $\mathrm{BBC}$ and the Commission of Government inhibited these bodies from 
fully understanding the distinctive character of broadcasting in Newfoundland, with its strong oral traditions.

As Simon J. Potter has noted, broadcasters from the dominions who visited the BBC 'often came away with the sense that the BBC was too bureaucratic and set in its ways, and that it remained oblivious to the nature and requirements of audiences and broadcasters in the dominions'. ${ }^{83}$ Dominion broadcasters also often 'lacked the resources required to act as effective imperial collaborators', ${ }^{84}$ and this was certainly the case in Newfoundland, where radio was consistently underfunded. As we have seen, although the $\mathrm{BBC}$ did begin to consider Commonwealth broadcasting as a pooling of resources with the 1945 conference, this ambition was far from being realised. Alongside the aforementioned issues regarding constitutional status and relative independence (Newfoundland having been regarded as equivalent to Southern Rhodesia, whose independence had not been legitimised), the Conference was also initially restrictive about what constituted independence in regard to public service broadcasting.

From the beginning the criterion of membership to which the Commonwealth Broadcasting Conference has clung has stubbornly been one of "public service", but this has been stretched to include, not merely those organisations fully protected in their independence by the license-fee [sic] system, but also those less protected (compare the BBC, which is not accountable on a day-to-day basis to Parliament, with the Canadian and Australian equivalents, which are); and to include those wholly dependent on government grants and those which are financed by both public funds and commercial revenues. ${ }^{85}$ 
Mapping the Broadcasting Corporation of Newfoundland against such distinctions does underscore the rather liminal public/private status of the Corporation, as it was financed by both commercial revenues and public funds, chiefly in the form of licence-fees. The question of its protection from Government scrutiny and intervention is more complex, but notwithstanding the view of the BBC's in-house lawyer R. Jardine Brown on reading the Broadcasting Act of 1938 that the BCN would be 'under the thumb of the Government', ${ }^{86}$ Webb refers to the 'arms-length relationship between the Commission and the Broadcasting Corporation', which gave the broadcaster 'autonomy from its owner' (e.g. in decisions about programming policy). ${ }^{87}$

This desire on the part of the Newfoundland population to safeguard its pre-existing radio culture undoubtedly acted as a brake upon the 'paternalistic and centralizing agenda of the British-born civil servants' ${ }^{88}$ Concern that suppression of other (commercial) stations would be regarded as 'tantamount to the suppression by the government of a competitor' meant that a 'mixed economy' of broadcasting did ultimately prevail, as in Canada. According to Webb, despite the reforming ambitions of the Commission of Government, there was thus a 'high degree of continuity in the kind of Newfoundland popular culture that was produced from VONF's early days as a privately owned commercial station through its decade as Newfoundland's state-owned broadcaster, up to the point that it was absorbed into the Canadian Broadcasting Corporation in $1949,{ }^{90}$ Sean Cadigan has cited the creation of the $\mathrm{BCN}$ as evidence that the Commission of Government was "willing to spend money on the moral reform of Newfoundlanders and Labradorians as long as such expenditures involved no fundamental restructuring of their economy'. ${ }^{91}$ Whether or not 'moral reform' as an outcome was achieved, or was even achievable through broadcasting, is beyond the scope of this article. But it would also appear to be the case that the BBC was willing to spend money on 
the consolidation of cultural ties with Newfoundland; as long as it had no impact on the colonial 'pecking order', and as long as it caused no embarrassment in Parliament.

\section{Acknowledgments}

Some of the research undertaken for this article was made possible by a bursary from Bournemouth University (Bournemouth-Memorial exchange programme) in 2007, to conduct travel to Newfoundland to conduct doctoral research. I would like to thank Jeff Webb for giving up his time to be interviewed by me about Newfoundland radio in 2007 and 2008, and for commenting on a draft of this article. Many thanks also to Patti Fulton and all the staff at the Memorial University Folklore and Language Archive, and to Ken Dahl and all the staff at the Provincial Archives of Saskatchewan.

\section{Notes}

${ }^{1}$ Simon J. Potter, Broadcasting Empire: The BBC and the British World, 1922-1970 (Oxford: OUP Oxford, 2012), 17.

${ }^{2}$ Potter, 7-8.

${ }^{3}$ Stephen Crocker, "Filmmaking and the Politics of Remoteness: The Genesis of the Fogo Process on Fogo Island, Newfoundland," Shima: The International Journal of Research into Island Cultures 2, no. 1 (2008): 73.

${ }^{4}$ Jeff Webb, "The Origins of Public Broadcasting: The Commission of Government and the Creation of the Broadcasting Corporation of Newfoundland," Acadiensis 24, no. 1 (1994): 89.

${ }^{5}$ This provided a meagre 6 cents per person per day, plus small amounts of tea, flour, pork and molasses. Neil Reynolds, "What Newfoundland Can Teach Us - The Globe and Mail," The Globe and Mail, March 5, 2018, https://www.theglobeandmail.com/report-onbusiness/rob-commentary/what-newfoundland-can-teach-us/article793205/.

${ }^{6}$ Its budget deficit was $\$ 3.5$ million, which surpassed 10 per cent of its GDP. See Reynolds.

${ }^{7}$ It can be noted that one important reason for public acceptance of this solution was that confidence in Newfoundland's own government had been eroded by scandals during the late 1920s and early 1930s.

${ }^{8}$ That this sense of dislocation, drift and conflicting loyalties was felt so keenly all these years after Confederation is testament to the massive and turbulent social change undergone by Newfoundland during the period under discussion. It is also testament to the continuing strength of these emotional and cultural ties and to the sense of divergence from mainland Canada, despite the lingering sense of attachment to the British Empire or Commonwealth, 
however problematic or tenuous. As the historian A. B. Perlin noted in the same programme, 'loyalty has to be won' and you can't 'discard one loyalty and don another as if you were changing a coat'. Between Ourselves: The Gulf (Part 1). Broadcast on CBN $8^{\text {th }}$ June 1966. Memorial University Folklore and Language Archive, MUNFLA F6219-F6220/C7056/82280.

${ }^{9}$ Michael Barkley to J. B. Clark, 'The Broadcasting Corporation of Newfoundland in Conversion', $29^{\text {th }}$ October 1948. BBC WAC E1/1105 Newfoundland Broadcasting Corporation File 1, 1943-1948.

${ }^{10}$ J. B. Clark (DDOS) to DOS, DG, DTS, CCS, HNAS, HOPS, 'Broadcasting Corporation of Newfoundland', $11^{\text {th }}$ November 1948. BBC WAC E1/1105 Newfoundland Broadcasting Corporation File 1, 1943-1948.

${ }^{11}$ Jeff Webb, The Voice of Newfoundland: A Social History of the Broadcasting Corporation of Newfoundland,1939-1949 (University of Toronto Press, 2008), 142.

${ }^{12}$ See Chapter 5 of Webb, 142-69.

${ }^{13}$ These factors prevented widespread distribution of any newspaper or publication, with the two Newfoundland dailies limited even by 1949 to a tiny circulation of roughly 12,000. Anon., 'Newfoundland Buys By Radio', Canadian Broadcaster \& Telescreen, 23 March 1949, p. 14.

${ }^{14}$ Mary Vipond, "British or American?: Canada's 'Mixed' Broadcasting System in the 1930s," The Radio Journal: International Studies in Broadcast \& Audio Media 2, no. 2 (September 2004): 91.

${ }^{15}$ Webb, The Voice of Newfoundland, 17.

${ }^{16}$ Michele Hilmes, "British Quality, American Chaos: Historical Dualisms and What They Leave Out," The Radio Journal: International Studies in Broadcast \& Audio Media 1, no. 1 (March 2003): 14.

${ }^{17}$ George H. Buck, "The First Wave: The Beginnings of Radio in Canadian Distance Education," International Journal of E-Learning \& Distance Education / Revue Internationale Du e-Learning et La Formation à Distance 21, no. 1 (June 1, 2006): 76-88. ${ }^{18}$ Webb. Interview with the present author, $13^{\text {th }}$ August 2008.

${ }^{19}$ In the city of Corner Brook in Western Newfoundland in 1945, for example, it was actually much easier to access programming from New York, Cincinnati, Nova Scotia, Prince Edward Island, and New Brunswick than it was to tune in to the radio stations broadcasting from the capital St John's (in the East). Janice Tulk, "“The Mill Whistle Was Blowing and the Germans Were Coming' : Industrial Soundscapes, World War II, and Remembrance in Corner Brook, Newfoundland," Ethnologies 34, no. 1-2 (2012): 196, https://doi.org/10.7202/1026150ar.

${ }^{20}$ Vipond, "British or American?: Canada's 'Mixed' Broadcasting System in the 1930s.”, p. 90.

${ }^{21}$ Webb, "The Origins of Public Broadcasting," 89.

${ }^{22}$ The German model of broadcasting, unlike the British, gave the provinces greater autonomy over broadcasting, which was important in Canada, as a federation of provinces. ${ }^{23}$ Anon., 'Newfoundland's Plans', World-Radio, 27 January 1939. Vol. XXVIII, No. 705, p. 9.

${ }^{24}$ See Webb, "The Origins of Public Broadcasting."

${ }^{25}$ Quoted in Sean Graham, "As Canadian as Possible: The Canadian Broadcasting Corporation, 1936-1939" (Thesis, Université d'Ottawa / University of Ottawa, 2014), 206, http://dx.doi.org/10.20381/ruor-880. 
${ }^{26}$ R. Jardine Brown to J.C.S. Macgregor (Empire Service Director), 'Newfoundland Broadcasting Corporation', $9^{\text {th }}$ December 1938. BBC WAC 'Broadcasting in Newfoundland, File 1b, 1936-1938. E1/1103/2.

${ }^{27}$ See Webb, "The Origins of Public Broadcasting," 92-94.

${ }^{28}$ R. A. Rendall to the Director-General William Haley, 'Broadcasting Corporation of Newfoundland', 22 ${ }^{\text {nd }}$ May 1945. BBC WAC E1/1105 Newfoundland Broadcasting Corporation File 1, 1943-1948.

${ }^{29}$ David Hale, "The Newfoundland Lesson," The International Economy, April 28, 2003, 53, www.international-economy.com.

${ }^{30}$ Potter, Broadcasting Empire, 7.

${ }^{31}$ Sian Nicholas, "'Brushing Up Your Empire': Dominion and Colonial Propaganda on the BBC's Home Services, 1939-1945," in Empire, Migration and Identity in the British World, ed. Kent Fedorowich and Andrew S. Thompson (Manchester University Press, 2017), 207.

${ }^{32}$ Nicholas, 223.

${ }^{33}$ Bert Riggs, "Margot Rhys Davies: Giving Voice to the Turmoil of the Second World War," Heritage: Newfoundland and Labrador, March 10, 1994, https://www.heritage.nf.ca/articles/society/margot-rhys-davies.php.

${ }^{34}$ Webb. Interview with the present author, $13^{\text {th }}$ August 2008.

${ }^{35}$ Quoted in 'Broadcasting in Newfoundland', report sent by Michael Barkway, the BBC's Canadian Representative to Controller (Overseas Service), $2^{\text {nd }}$ April 1946. BBC WAC E1/1105 Newfoundland Broadcasting Corporation File 1, 1943-48.

${ }^{36}$ The BBC did invite the Trade Commissioner D. J. Davies (or a representative) to 'a special representative session' of the conference, and did also signal their willingness to consider inviting Newfoundland and other members to future conferences, although these seem rather token gestures in retrospect.

${ }^{37}$ Anon., 'The Overseas Service', BBC Year Book 1946, p. 96.

${ }^{38}$ Potter, Broadcasting Empire, 78.

${ }^{39}$ Anon., 'The Overseas Service', p. 97.

${ }^{40}$ These programmes were intended to suit the particular needs of each audience, and the schedule of the broadcasting country. S. Potter, "Britishness, the BBC, and the Birth of Canadian Public Broadcasting, 1928-1936,” ed. Gene Allen and Daniel Robinson, Communicating in Canada's Past: Approaches to the History of Print and Broadcast Media, 2009, 81 .

${ }^{41}$ Kenneth Adam, "The Commonwealth Broadcasting Conference," in Broadcasting in Africa: A Continental Survey of Radio and Television, ed. Sydney W. Head (Temple University Press, 1974), 265.

${ }^{42}$ Potter, Broadcasting Empire, 12.

${ }^{43}$ Jeff Webb, personal communications with the present author, 9 December 2018.

${ }^{44}$ Quoted in Potter, Broadcasting Empire, 141.

${ }^{45}$ Nicholas, "'Brushing Up Your Empire': Dominion and Colonial Propaganda on the BBC's Home Services, 1939-1945,” 215.

${ }^{46}$ Quoted in Potter, Broadcasting Empire, 154-55.

${ }^{47}$ The North American Service clearly resented the idea that the BBC neglected

Newfoundland, providing as it did the regular Calling Newfoundland and Newfoundland Newsletter programmes long after all similar programmes had been discontinued.

48 This included two contributions to Family Gathering, a North Region series which comprised recorded interviews from the dominions, in which 'ordinary people' who had migrated from the north of England during the 1920s and 1930s sent messages to relatives at home, and discussed life and work overseas. See Potter, Broadcasting Empire, 186. 
${ }^{49}$ Michael Barkway, 'Broadcasting in Newfoundland', $2^{\text {nd }}$ April 1946. BBC WAC E1/1105 Newfoundland Broadcasting Corporation File 1, 1943-48.

${ }^{50}$ Webb, The Voice of Newfoundland, 54.

${ }^{51}$ Quoted in Graham, "As Canadian as Possible," 207.

${ }^{52}$ Quoted in Webb, "The Origins of Public Broadcasting," 97.

${ }^{53}$ Minutes of 'Broadcasting in Newfoundland' meeting, Dominions Office, $2^{\text {nd }}$ February 1938. BBC WAC 'Broadcasting in Newfoundland, File 1b, 1936-1938. E1/1103/2.

${ }^{54}$ Potter, Broadcasting Empire, 13.

${ }^{55}$ Len Kuffert, Canada before Television: Radio, Taste, and the Struggle for Cultural Democracy (McGill-Queen's Press - MQUP, 2016), 111.

${ }^{56}$ J.C.S Macgregor to Overseas Services Executive, 'Empire Transcription Programmes for Newfoundland', 28 ${ }^{\text {th }}$ October 1938. BBC WAC E5/55 Empire Transcriptions, Newfoundland Broadcasting Corporation 1938-40.

${ }^{57}$ Kuffert, Canada before Television, 112.

${ }^{58} \mathrm{Webb}$, The Voice of Newfoundland, 27.

${ }^{59}$ Webb, The Voice of Newfoundland, 171.

${ }^{60}$ Potter, Broadcasting Empire, 10.

${ }^{61}$ See Webb, The Voice of Newfoundland, 174-178.

${ }^{62}$ Webb, The Voice of Newfoundland, 26.

${ }^{63}$ Smallwood made use of the pseudonym 'The Barrelman' for his newspaper column (entitled 'From the Masthead) in the St John's Daily News. For some years this ran concurrently with the radio programme. See also Peter Narváez, "Joseph R. Smallwood, The Barrelman: The Broadcaster as Folklorist," in Media Sense: The Folklore-Popular Culture Continuum, ed. Peter Narváez and Martin Laba (Popular Press, 1986), 47-64.

${ }^{64}$ Jeff Webb. Interview with the present author, St. John's, 30 ${ }^{\text {th }}$ July 2007.

${ }^{65}$ Webb, The Voice of Newfoundland, 115.

${ }^{66}$ Webb, 115.

${ }^{67}$ Research by Don Jamieson commissioned in 1949 by the commercial station VOCM (which also carried BBC news) found 'communal listening' on a 'selective' basis to be still widespread, with the number of listening hours per day for battery set owners estimated at between $3 \frac{1}{2}$ and 4. Cited in Anon., 'Newfoundland Buys By Radio'.

${ }^{68}$ Kevin O'Connell, Interviewed by Hector Swain, September 20, 1990, http://collections.mun.ca/cdm/ref/collection/ich_avalon/id/6225.

${ }^{69}$ Young, E. 'All The News from All Over Newfoundland', Atlantic Guardian, Vol. 3, No. 2, February 1947, pp. 21.

${ }^{70}$ Much of this information is sourced from internal documentation within the Provincial Archives of Saskatchewan. Information on the Jean Doidge accession can be found here http://sain.scaa.sk.ca/collections/index.php/jean-doidge-fonds;rad

${ }^{71}$ Script information taken from the Northern News radio scripts. Provincial Archives of Saskatchewan, R-2.1093, Reel 7 of 11.

${ }^{72}$ Philip Hiscock, "Folk Programming Versus Elite Information: The 'Doyle Bulletin' and the 'Public Despatch", Culture and Tradition, Vol. 12 (1988), p. 42.

${ }^{73}$ Hiscock, 'Radio Country', 40.

${ }^{74}$ Hiscock, 'Folk Programming', 45.

${ }^{75}$ Hiscock, 'Folk Programming', 45.

${ }^{76}$ Communications media, in 'trespassing' into the domestic sphere and bringing news and culture from 'the outside world', have often been blamed for supplanting and eroding oral tradition and traditional social patterns within rural areas. However, during the early decades of radio in Newfoundland, the gathering of people in outport kitchens around the radio 
receiver appears to have represented more of a mediation or restructuring of existing social traditions and visiting customs.

${ }^{77}$ Hiscock, 'Folk Programming', 49.

${ }^{78}$ Philip Hiscock, "Folklore and Popular Culture in Early Newfoundland Radio Broadcasting: An Analysis of Occupational Narrative, Oral History and Song Repertoire" (masters, Memorial University of Newfoundland, 1986), 99, https://research.library.mun.ca/5482/.

${ }^{79}$ Barkway, 'Broadcasting in Newfoundland'.

${ }^{80}$ Webb, interview with the present author, $30^{\text {th }}$ July 2007.

${ }^{81}$ For an in-depth study of this programme, see Philip Hiscock, "The Barrelman Radio Programme, 1937-1943: The Mediation and Use of Folklore in Newfoundland" (doctoral, Memorial University of Newfoundland, 1994), https://research.library.mun.ca/10659/.

${ }^{82}$ Jesus Martín-Barbero, Communication, Culture and Hegemony: From the Media to Mediations (SAGE Publications, 1993), 170.

${ }^{83}$ S. Potter, "The Colonization of the BBC: Diasporic Britons at BBC External Services, c. 1932-1970," ed. Marie Gillespie and Alban Webb, Diasporas and Diplomacy: Cosmopolitan Contact Zones at the BBC World Service, 1932-2012, 2013, 43.

${ }^{84}$ Potter, Broadcasting Empire, 78.

${ }^{85}$ Adam, "The Commonwealth Broadcasting Conference," 266.

${ }^{86}$ R. Jardine Brown to J.C.S. Macgregor (Empire Service Director), 'Newfoundland Broadcasting Corporation', $9^{\text {th }}$ December 1938. BBC WAC 'Broadcasting in Newfoundland', File 1b, 1936-1938. E1/1103/2.

${ }^{87}$ Webb, The Voice of Newfoundland, 130.

${ }^{88}$ Webb, The Voice of Newfoundland, 8.

${ }^{89}$ Letter from William Horwood to Malcolm Macdonald MP, $2^{\text {nd }}$ April 1938. BBC WAC 'Broadcasting in Newfoundland', File 1cm 1938-1940.

${ }^{90}$ Webb, The Voice of Newfoundland, 8.

${ }^{91}$ Sean T. Cadigan, Newfoundland and Labrador: A History (University of Toronto Press, 2009), 222. 
Ieuan Franklin is Lecturer in Media and Cultural History at Bournemouth University. He was lead editor (with Prof. Hugh Chignell and Dr Kristin Skoog) of Regional Aesthetics: Mapping UK Media Cultures (Palgrave, 2015) and is currently working on a monograph exploring the relationship between oral history and radio broadcasting. 